\title{
Pengaruh Efikasi Diri dan Lokus Kendali terhadap Kinerja Karyawan Melalui Learning Agility
}

\author{
Anizzibda Chahya Khildani ${ }^{\left.1^{*}\right)}$, Suhermin ${ }^{2)}$, Marsudi Lestariningsih ${ }^{3)}$ \\ ${ }^{\left.1^{*}, 2,3\right)}$ Magister Manajemen, Sekolah Tinggi Ilmu Ekonomi (STIESIA) Surabaya \\ Jalan Menur Pumpungan No. 30, Surabaya, Jawa Timur, 60118 \\ Email: Penulis korespondensi: anizzibda@gmail.com
}

\begin{abstract}
ABSTRAK
Penelitian ini menginvestigasi pengaruh efikasi diri dan lokus kendali terhadap kinerja karyawan melalui learning agility pada PT Bank Pan Indonesia - cabang Tanjung Perak Surabaya. Teknik pengumpulan data menggunakan purposive sampling untuk mendapatkan sampel penelitian sebanyak 32 responden. Penelitian hipotesis menggunakan Partial Least Square (PLS). Hasil penelitian menunjukkan bahwa efikasi diri secara langsung maupun melalui learning agility berpengaruh positif dan signifikan terhadap kinerja karyawan pada PT Bank Pank Indonesia Tbk. Sedangkan learning agility berpengaruh positif dan tidak signifikan terhadap kinerja karyawan pada PT Bank Pan Indonesia Tbk - cabang Tanjung Perak Surabaya. Variabel lokus kendali secara langung dan melalui learning agility berpengaruh positif dan tidak signifikan terhadap kinerja karyawan pada PT Bank Pan Indonesia Tbk - cabang Tanjung Perak Surabaya.
\end{abstract}

Kata kunci: Efikasi Diri; Kinerja Karyawan; Learning Agility; Lokus Kendali.

\begin{abstract}
This research investigated the effect of self-efficacy and locus of control on the employee performance through learning agility of PT Bank Pan Indonesia branch Tanjung Perak Surabaya. The data collection technique used purposive sampling to obtain research sample of 32 respondents. By using Partially Least Square, the results show that self-efficacy, either directly or through learning agility, had positive and significant effect on the employee performance of PT Bank Pan Indonesia - Tanjung Perak Surabaya branch, On the other hand, learning agility, had positive and insignificant effect on the employee performance of PT Bank Pan Indonesia Tbk -Tanjung Perak Surabaya branch, locus of control directly and through learning agility had insignificant and positive effect on the employee performance of PT Bank Pan Indonesia Tbk-Tanjung Perak Surabaya branch.
\end{abstract}

Keyword: Employee Performance; Learning Agility; Locus ff Control; Self Efficacy. 


\section{PENDAHULUAN}

Bank Panin menjadi bank terbesar ke delapan dari 110 bank di Indonesia berdasarkan catatan Otoritas Jasa Keuangan dengan total aset yang dimiliki sejumlah Rp 218 triliun pada tahun 2020 (Otoritas Jasa Keuangan, 2020). Tidak hanya itu, PT Bank Pan Indonesia, Tbk juga memiliki banyak prestasi seperti Indonesian Information Technology Award 12019 dan kategori bank buku 4 oleh Bank Indonesia 2020 (Panin Bank, 2020). Banyaknya pencapaian yang diperoleh oleh PT Bank Pan Indonesia, Tbk merupakan pencapaian kinerja yang bagus. Namun PT Bank Pan Indonesia, Tbk tetap harus meningkatkan kinerjanya agar tetap dapat meningkatkan eksistensinya, salah satu caranya dengan mengevaluasi kinerja para karyawan yang tersebar di berbagai cabang. Keberhasilan perusahaan tidak lepas dari kolaborasi antara beberapa karyawan dari berbagai bidang, karena kinerja karyawan yang baik akan berdampak pada citra perusahaan. Seperti halnya pada PT Bank Pan Indonesia, Tbk - cabang Tanjung Perak Surabaya, meskipun kinerja perusahaan tergolong cukup baik tetapi masih terdapat kendala pada kinerja karyawannya. Berikut merupakan hasil penilaian kinerja karyawan menurut pimpinan PT Bank Pan Indonesia, Tbk - cabang Tanjung Perak Surabaya

Kinerja karyawan merupakan hasil atau tingkat keberhasilan seseorang secara keseluruhan selama periode tertentu di dalam melaksanakan tugas dibandingkan dengan semua kemungkinan seperti standar hasil kerja, target, sasaran atau kriteria yang telah disepakati bersama (Mangkunegara, 2014). Kinerja yang baik dapat dicerminkan dari kuantitas dan kualitas hasil pekerjaan yang telah diselesaikan oleh karyawan dalam melaksanakan tugas dan tanggungjawabnya. Apabila kinerja para pegawai optimal maka akan memberikan dampak positif bagi organisasi dan apabila kinerja kurang optimal maka akan sulit bagi suatu organisasi untuk mencapai tujuan, visi dan misi. Seperti halnya pada PT Bank Pan Indonesia, Tbk - cabang Tanjung Perak Surabaya, terdapat kendala pada kinerja karyawannya. Berdasarkan wawancara tertutup yang dilakukan kepada subbranch manager PT Bank Pan Indonesia, Tbk - cabang Tanjung Perak Surabaya kinerja karyawan dinilai masih belum cukup optimal, pencapaian target yang bagus dengan $85 \%$ karyawan mampu menyeselaikan target yang telah ditetapkan perusahaan, namun tidak diimbangi dengan pencapaian hasil kinerja yang melebihi standar kerja perusahaan hanya sebesar 25\% karyawan. Karyawan hanya bisa menyelesaikan target pekerjaan dan sedikit yang menyelesaikan pekerjaan diatas standar kerja yang hanya sekedar menggugurkan kewajiban tanpa melakukan inovasi pada pekerjaannya. Hal ini berarti pekerjaan yang diberikan terlalu monoton. Karyawan tidak memiliki inisiatif, pembaharuan, inovasi terhadap pekerjaannya 
dan tidak suka dengan tantangan. Sehingga, apabila karyawan hanya melakukan pekerjaan yang sama dan berulang-ulang maka mereka tidak dapat dikategorikan sebagai talent pool untuk dapat dipertimbangkan menjadi future leader. Apabila karyawan melakukan pekerjaan dengan hasil yang standar, mereka hanya akan menempati jabatan yang sama dari awal pekerjaannya tanpa adanya kenaikan jabatan.

Sejalan dengan temuan yang dilakukan oleh peneliti kepada 15 karyawan PT Bank Pan Indonesia, Tbk - cabang Tanjung Perak Surabaya. Kinerja karyawan baik dengan tidak suka menunda pekerjaan sebanyak 12 orang, namun hanya 4 dari 11 karyawan yang suka mengerjakan melebihi standar kerja dan menyukai mempelajari hal baru. Ketidaksukaan menunda pekerjaan dan sedikit yang mengerjakan tugas dengan baik, berarti bahwa karyawan berusaha untuk menyelesaikan target pekerjaan yang banyak dan monoton sehingga mereka memprioritaskan ketepatan waktu pengumpulan tugas agar bisa mencapai target yang telah ditetapkan perusahaan. Jika hal ini terus berlanjut dan menjadi budaya di suatu perusahaan, akan berdampak negatif pada pola pikir dan sikap karyawan. Karyawan menjadi tidak kreatif dan tidak suka melakukan inovasi terhadap pekerjaannya yang berdampak pada kurang sukanya dalam melakukan hal-hal baru untuk pengembangan diri sendiri dan kurangnya loyalitas terhadap perusahaan.

Mempelajari hal baru merupakan hal penting dari sebuah pekerjaan, hal tersebut dapat menambah value kita sebagai karyawan dimata manajemen karena dianggap sebagai karyawan yang berpotensial, mudah beradaptasi terhadap perubahan yang akan dipertimbangkan sebagai talent poll untuk menjadi next future leader didalam suatu perusahaan. Mau ataupun tidak mau karyawan tetap dituntut untuk bisa cepat menghadapi perubahan dan belajar dengan waktu yang singkat mengingat ketidakpastian bisnis dimasa mendatang sehingga perusahaan akan pembaharuan dan perbaikan dengan menerbitkan produk, fitur dan kebijakan baru untuk bisa bertahan dan bersaing dengan perusahaan sejenis. Karyawan yang tidak bisa beradaptasi terhadap perubahan akan menyulitkan dirinya sendiri dalam melaksanakan tugasnya dan sulit untuk menaiki jabatan.

Peningkatan skill dan pengetahuan sangat penting bagi karyawan untuk meningkatkan kinerjanya. Pengukuran kinerja perusahaan merupakan salah satu faktor penting dalam perusahaan untuk menilai keberhasilan suatu kinerja pada karyawannya. Kinerja karyawan merupakan sesuatu yang dapat dihasilkan dalam periode tertentu dengan mengacu kepada standar yang ditetapkan oleh perusahaan. Karyawan yang baik adalah karyawan yang mampu bekerja sesuai target yang telah ditetapkan perusahaan agar tercapainya visi perusahaan untuk tetap terus berlangsung dan bertahan dalam jangka waktu yang lama. Wibowo (2017) 
menyatakan terdapat beberapa dampak dari kinerja karyawan, yaitu dapat memperbaiki kinerja perusahaan (bisa mengetahui keterampilan yang diperlukan, kepercayaan diri meningkat, mengelola fleksibilitas pribadi), memperbaiki kinerja individu (mengetahui cara belajar yang baik, emosi terkontrol, menemukan pendekatan terbaik dalam menghadapi masalah, belajar mengurangi kebiasaan buruk, kemampuan analisa masalah yang baik, penggunaan waktu yang optimal) membantu orang lain menjadi lebih baik (komunikasi nonverbal yang lebih baik, mengerti skala prioritas, bekerja sesuai dengan sifat kepribadiannya, peka terhadap masalah, memperbaiki hubungan kerja). Karyawan merupakan aset suatu perusahaan yang harus dijaga dan diperhatikan agar dapat memberikan kinerja terbaiknya dalam menjalankan operasional perusahaan. Manajemen perusahan harus memperhatikan faktor-faktor yang dapat mempengaruhi kinerja karyawan agar dapat mengontrol dan meningkatkan kinerja karyawannya. Indikator kinerja karyawan menurut Manthis dan Jackson (2011), yaitu kuantitas pekerjaan, kualitas pekerjaan, ketepatan waktu, kehadiran, dan kemampuan bekerjasama.

Teori atribusi dapat digunakan sebagai bahan pengkajian lebih lanjut mengenai faktorfaktor yang mempengaruhi kinerja karyawan. Teori atribusi mengacu kepada bagaimana seseorang menjelaskan penyebab perilaku dirinya sendiri atau orang lain (Luthas, 2006: 209). Menurut teori atribusi yang dicetuskan oleh Fritz Heider pada tahun 1958 terdapat tiga faktor yang memengaruhi kinerja yaitu faktor individu yang berasal dari dalam diri seseorang, faktor psikologis, dan faktor organisasi (Choiriah, 2013). Faktor yang memengaruhi kinerja karyawan yang berasal dari dalam diri, yaitu efikasi diri. Faktor yang terkait dengan unsur psikologis manusia, yaitu lokus kendali dan learning agility. Sedangkan faktor organisasional yang akan memengaruhi kinerja karyawan yaitu peraturan dan target yang telah ditetapkan perusahaan.

Dalam mencapai kinerja yang optimal karyawan perlu memiliki kemampuan belajar yang baik dan beradaptasi dengan segala perubahan yang ada. Learning agility merupakan kemampuan dan kesediaan seseorang untuk belajar dari pengalamannya, kemudian hal yang telah dipelajari diterapkan untuk mendapatkan solusi dan kesuksesan di situasi yang baru (Muse, et al., 2010). Individu dengan agility tinggi akan mampu belajar dari pengalaman dan menerapkan pelajaran tersebut di situasi baru, aktif mencari feedback dari temannya sebagai bahan koreksi agar dapat tumbuh dan berkembang, cenderung menyukai tantangan, refleksi diri, mengevaluasi pengalamannya dan menarik kesimpulan (Meuse, et al., 2019). Tingginya learning agility seseorang akan dapat memudahkan dalam menghadapi tantangan suatu pekerjaan. Indikator learning agility menurut Eichinger dan Lombardo (dalam Meuse, 
2017:270) adalah people agility, yaitu sejauh mana seseorang mengetahui dirinya dengan baik, belajar dari pengalaman, suka bersosialisasi dan open minded dengan orang lain, dapat menempatkan dan melibatkan orang lain dengan melihat kelebihan dan keterbatasan seseorang; result agility, yaitu sejauh mana seseorang mengetahui dirinya dengan baik, belajar dari pengalaman, suka bersosialisasi dan open minded dengan orang lain, dapat menempatkan dan melibatkan orang lain dengan melihat kelebihan dan keterbatasan seseorang; mental agility, yaitu sejauh mana individu memikirkan suatu masalah dari sudut pandang baru, mampu berpikir kritis terhadap persoalan yang kompleks, dan menjelaskan pemikiran mereka kepada orang lain; dan change agility, yaitu individu memiliki rasa ingin tahu yang tinggi dengan mengeksplor hal-hal baru, suka terhadap perubahan, tidak cepat merasa puas akan pencapaiannya, dan senang terlibat dalam aktivitas pengembangan keterampilan.

Dalam bekerja karyawan dituntut tidak hanya bisa melakukan tugasnya dengan baik, tetapi juga dapat melakukan pekerjaan secara cepat dan mampu menciptakan ide-ide baru sebagai sebuah bentuk inovasi. Banyak karyawan yang memiliki nilai IQ tinggi merasa kemampuan mereka sudah cukup memumpuni dalam bekerja sehingga tidak mau lagi mempelajari hal baru. Jika terdapat kesalahan di pekerjaannya, karyawan yang memiliki karakteristik seperti ini suka menyalahkan orang lain, tidak mau merefleksi diri, dan merasa dirinyalah yang paling benar. Karyawan seperti ini biasanya tidak dapat bertahan lama karena ketidakmauan untuk belajar hal baru dan belajar dari kesalahannya yang membuat mereka kesusahan sendiri dalam bekerja. Kinerja karyawan semakin baik jika karyawan memiliki intelligence quotient (IQ) yang tinggi dan diikuti oleh emotional quotient (EQ) yang tinggi berupa kemauan mempelajari hal yang belum pernah diketahui sebelumnya. Pengetahuan seseorang perlu ditingkatkan karena dunia ini dinamis dan sering berubah, begitu pula ditempat kerja.

Mengingat pentingnya learning agility seorang karyawan dalam meraih kesuksesan dan keberlangsungan perusahaan, sekitar tahun 2000 perusahaan mulai menerapkan konsep learning agility dalam proses recruitment. Penelitian learning agility terus berkembang di luar negeri, namun masih minimnya kajian tentang learning agility di Indonesia dan terdapat perbedaan hasil penelitian mengenai pengaruhnya terhadap kinerja karyawan sehingga perlu adanya pengkajian ulang. Perbedaan pendapat tersebut ditunjukkan oleh Drinka (2018) yang menyatakan bahwa hasil penelitiannya tidak memverifikasi hubungan antara learning agility dan kinerja karyawan. Sedangkan pendapat Saputra et al. (2018) yang menyatakan bahwa learning agility memiliki pengaruh positif signifikan terhadap work engagement yang akan berdampak pada kinerja karyawan. Pendapat yang sama juga dikemukakan oleh Bedford 
(2011), Allen (2016), dan Meuse (2019) yang menyatakan terdapat hubungan antara learning agility dan kineja.

Keyakinan diri merupakan hal penting dalam menumbuhkan semangat bekerja, keyakinan diri tersebut dapat disebut dengan efikasi diri. Efikasi diri menurut Bandura (2011) adalah keyakinan terhadap kemampuan diri seseorang dalam melaksanakan tugas atau tindakan yang diperlukan untuk mencapai hasil tertentu. Keyakinan seseorang tehadap kemampuan dirinya dapat membantu menyelesaikan pekerjaannya secara optimal karena hal tersebut membuat seseorang tidak ragu terhadap apa yang akan atau telah mereka kerjakan. Efikasi diri merupakan faktor individu yang dapat berubah, perubahan efikasi diri dapat berdampak pada perubahan perilaku saat bekerja terutama dalam menyelesaikan tugas dan tujuan. Efikasi diri adalah penentu kesiapan belajar individu. Saat mengerjakan tugas yang sulit, karyawan yang memiliki efikasi diri tinggi akan berusaha belajar dan cenderung tidak mudah menyerah meskipun lingkungan tidak kondusif. Apabila kepercayaan diri telah tertanam namun tetap tidak bisa meningkatkan kinerja karyawan, hal ini bisa jadi karena karyawan percaya bahwa terdapat hal lain diluar dirinya yang bisa mengontrol hidupnya. Indikator efikasi diri menurut Chasanah (dalam Rofi, 2019:100) yaitu perasanaan mampu melakukan pekerjaan, kemampuan yang lebih baik, senang pekerjaan yang menantang, dan kepuasan terhadap pekerjaan. Pertimbangan penulis memilih variabel efikasi diri karena terdapat perbedaan hasil antar peneliti, sehingga perlu adanya pengkajian ulang untuk membuktikan kebenaran teori yang ada. Perbedaan pendapat tersebut ditunjukkan oleh Dewi dan Tenaya (2017), Mukrodi (2018), Zaki, et al (2019), Rofi (2019) yang menyatakan bahwa efikasi diri memiliki pengaruh positif signifikan terhadap kinerja karyawan. Sedangkan menurut Hikmah (2020) menyatakan bahwa efikasi diri berpengaruh positif tidak signifikan terhadap kinerja karyawan. Sehingga masih terjadi research gap antara efikasi diri terhadap kinerja karyawan dan perlu pengkajian ulang hubungan antara efikasi diri terhadap kinerja karyawan.

Kinerja seorang karyawan dipengaruhi olah faktor psikologis seperti lokus kendali. Persepsi siapakah orang yang berperan penting di dalam hidupnya bisa mempengaruhi cara karyawan bersikap dalam menyelesaikan pekerjaannya. Lokus kendali merupakan cara pandang seseorang apakah mereka dapat mengendalikan atau tidak dapat mengendalikan sesuatu peristiwa yang terjadi pada dirinya (Amalini, et al., 2016). Pengendalian diri yang baik akan membuat individu menjadi lebih tangguh dalam menghadapi kesulitan dalam kehidupan ataupun pekerjaannya sehingga mereka akan berfokus pada hasil. Terdapat 2 jenis lokus kendali, yaitu lokus kendali internal dan lokus kendali eksternal. Indikator lokus kendali 
menurut Crider (dalam Amalini, et al., 2016:70), yaitu lokus kendali internal; suka bekerja keras, memiliki inisiatif yang tinggi, selalu berusaha untuk menemukan pemecahan masalah selalu mencoba untuk berfikir seefektif mungkin, selalu mempunyai persepsi bahwa usaha harus dilakukan jika ingin berhasil dan lokus kendali eksternal; mudah menyerah, kurang mencari informasi, mempunyai harapan bahwa ada korelasi antara usaha dan kesuksesan, mudah dipengaruhi dan bergantung pada petunjuk orang lain, dan selalu berfikir bahwa kejadian dalam hidup merupakan akibat peran dari orang yang berkuasa. Pertimbangan penulis memilih variabel lokus kendali karena terdapat perbedaan hasil antar peneliti, sehingga perlu adanya pengkajian ulang untuk membuktikan kebenaran teori yang ada. Perbedaan pendapat tersebut ditunjukkan oleh Subroto (2017) dan Amalini et al (2016) yang menyatakan bahwa terdapat pengaruh tidak signifikan lokus kendali terhadap kinerja karyawan. Pernyataan tersebut bertentangan dengan Modise dan Rambe (2017), Nainggolan, et al (2018), Saprudin, et al (2019) bahwa terdapat pengaruh positif signifikan antara lokus kendali terhadap kinerja karyawan. Jika ingin meningkatkan kinerja karyawan, maka harus memperhitungkan lokus kendali para pegawai. Sehingga perlu pengkajian ulang hubungan antara lokus kendali terhadap kinerja karyawan.

Berdasarkan latar belakang masalah dan gab research yang telah dijelaskan sebelumnya, maka penulis tertarik meneliti "Pengaruh Efikasi Diri dan Lokus Kendali terhadap Kinerja Karyawan melalui Learning Agility" dengan 5 hipotesis penelitian, yaitu efikasi diri berpengaruh terhadap kinerja karyawan; lokus kendali berpengaruh terhadap kinerja karyawan; learning agility berpengaruh terhadap kinerja karyawan; efikasi diri berpengaruh terhadap kinerja karyawan melalui learning agility; dan lokus kendali berpengaruh terhadap kinerja karyawan melalui learning agility.

\section{METODE PENELITIAN}

Penelitian ini menggunakan pendekatan kuantitatif. Metode penelitian kuantitatif melakukan pengumpulan data menggunakan instrument penelitian dengan analisis data yang besifat statistik atau kuantitatif pada sebuah sampel atau populasi tertentu, yang betujuan untuk menguji hipotesis penelitian (Sugiyono, 2017). Penelitian ini digunakan untuk mengetahui pengaruh efikasi diri dan lokus kendali terhadap kinerja karyawan melalui learning agility pada karyawan PT Bank Pan Indonesia, Tbk - cabang Tanjung Perak Surabaya. Sugiyono (2017) mengatakan bahwa populasi merupakan wilayah generalisasi subjek atau objek dengan karakteristik dan kualitas tertentu yang ditetapkan oleh peneliti untuk dipelajari dan ditarik kesimpulannya. Objek (populasi) dalam penelitian ini adalah 
karyawan pada PT Bank Pan Indonesia Tbk - Cabang Tanjung Perak Surabaya yang masih bekerja sejumlah 45 karyawan dengan jumlah sampel sebanyak 32 responden dari karyawan PT Bank Pan Indonesia, Tbk - cabang Tanjung Perak Surabaya diperoleh dari teknik purposive sampling. Sampel penelitian dipilih berdasarkan pertimbangan tertentu untuk memperoleh sampel yang memiliki karakteristik dan kriteria yang sesuai oleh peneliti disebut dengan purposive sampling.

Kriteria pada penelitian ini yaitu, pegawai PT Bank Pan Indonesia, Tbk - cabang Tanjung Perak Surabaya, telah bekerja minimal 3 bulan di PT Bank Pan Indonesia Tbk cabang Tanjung Perak Surabaya, memiliki pendidikan minimal diploma tiga, bukan sebagai subbranch manager dan manager perdivisi PT Bank Pan Indonesia Tbk - cabang Tanjung Perak Surabaya. Jenis data yang digunakan adalah data subjek. Data subjek merupakan jenis data yang berupa sikap, opini, karakteristik atau pengalaman seseorang, dalam penelitian ini yaitu karyawan PT Bank Pan Indonesia Tbk - Cabang Tanjung Perak Surabaya yang digunakan sebagai responden penelitian. Sumber data penelian ini menggunakan sumber data primer. Data primer adalah sumber data yang langsung memberikan data kepada pengumpul data. Data primer penelitian ini diperoleh dari wawancara kepada subbranch manager dan kuesioner kepada karyawan PT Bank Pan Indonesia, Tbk - cabang Tanjung Perak Surabaya.

Pengukuran kinerja karyawan sebagai variabel dependen didasarkan pada instrument yang dikembangkan oleh Mathis dan Jackson (2011) terdiri dari 5 item pertanyaan berdasarkan 5 indikator yaitu kuantitas pekerjaan, kualitas pekerjaan, ketepatan waktu, kehadiran, dan kemampuan bekerjasama. Pengukuran learning agility sebagai variabel intervening didasarkan pada instrument yang dikembangkan oleh Eichinger dan Lombardo (dalam Meuse, 2017) yang terdiri dari 4 item pertanyaan berdasarkan 4 indikator, yaitu people agility, result agility, mental agility, dan change agility.

Pengukuran efikasi diri sebagai variabel independen didasarkan pada instrument yang dikembangkan oleh Chasanah (dalam Rofi, 2019) yang terdiri dari 4 item pertanyaan berdasarkan 4 indikator yaitu perasaan mampu melakukan pekerjaan, kemampuan yang lebih baik, senang pekerjaan yang menantang, dan kepuasan terhadap pekerjaan. Sedangkan Pengukuran lokus kendali sebagai variabel independen didasarkan pada instrument yang dikembangkan oleh Crider (dalam Amalini et al., 2016) yang terdiri dari 5 item pertanyaan berdasarkan 5 indikator yaitu selalu mempunyai persepsi bahwa usaha harus dilakukan jika ingin berhasil, kurang mencari informasi, mudah menyerah, kurang suka berusaha karena mereka percaya bahwa faktor luarlah yang mengontrol, mudah dipengaruhi orang lain, dan mempercayai kejadian dalam hidup merupakan akibat dari peran orang yang berkuasa. 
Masing-masing instrument penelitian diukur dengan menggunakan skala likert 1-5 dari sangat tidak setuju sampai sangat setuju.

Metode statistik yang digunakan dalam penelitian ini adalah program Smart PLS (Partial Least Square) yang terdiri dari diagram jalur, uji outer model, analisis statistik deskriptif, dan uji inner model. Model PLS memiliki kelebihan bisa menekankan prediksi berakurasi tinggi, data tidak harus berdistribusi normal, bisa digunakan untuk sampel ukuran kecil lebih dari 100 sampel, mampu menguji model jalur dengan konstruk formatif atau reflektif bahkan bisa keduanya sekaligus (Santosa, 2018). Nilai rata-rata kelompok dalam 5 interval kelas. Panjang interval kelas sapat dihitung menggunakan rumus berikut:

$$
\text { Interval Kelas }=\frac{\text { Nilai Tertinggi }- \text { Nilai Terendah }}{\text { Jumlah Kelas }}=\frac{5-1}{5}=0,8
$$

\section{Tabel 1. Distribusi Interval Kelas Variabel Penelitian}

\begin{tabular}{ccc}
\hline Interval & Skor & Kategori \\
\hline $4,20<\mathrm{a} \leq 5,00$ & 5 & Sangat Setuju (SS) \\
$3,40<\mathrm{a} \leq 4,20$ & 4 & Setuju (S) \\
$2,60<\mathrm{a} \leq 3,40$ & 3 & Kurang Setuju (KS) \\
$1,80<\mathrm{a} \leq 2,60$ & 2 & Tidak Setuju (TS) \\
$1,00<\mathrm{a} \leq 1,80$ & 1 & Sangat Tidak Setuju (STS) \\
\hline
\end{tabular}

Sumber: Sugiyono (2017)

\section{HASIL DAN PEMBAHASAN}

Analisis diagram jalur dilakukan sebelum melakukan analisis untuk memudahkan melihat hubungan antar variabel. Berikut diagram jalur pada penelitian ini yang menggunakan aplikasi SmartPLS 3,0:

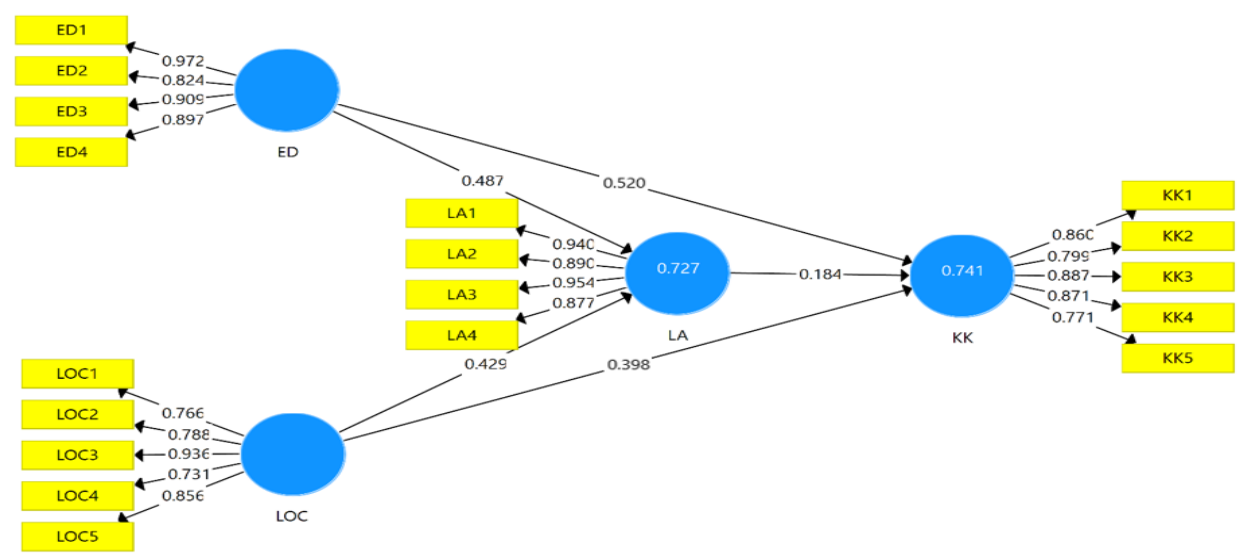

Gambar 1. Hasil Frame Work Diagram Jalur

Sumber: data diolah, 2021

Berdasarkan gambar frame work diagram jalur dapat diketahui bahwa model persamaan sub struktural yang terbentuk dalam penelitian ini antara lain sebagai berikut: 
Model Persamaan 1

$\mathrm{LA}=0,487 \mathrm{ED}+0,429 \mathrm{LOC}$

Model Persamaan 2

$\mathrm{KK}=0,520 \mathrm{ED}+0,398 \mathrm{LOC}+0,184 \mathrm{LA}$

Pada model persamaan 1 nilai koefisien jalur b1 sebagai penghubung variabel efikasi diri (ED) ke learning agility (LA) bernilai positif sebesar 0,487. Hal ini menunjukkan bahwa apabila efikasi diri (ED) naik sebesar satu satuan maka learning agility (LA) akan meningkatkan sebesar 0,487 dengan asumsi variabel lainnya konstan atau 0 (nol). Koefisien jalur b2 sebesar 0.429 dan bernilai positif, hal ini menandakan bahwa hubungan lokus kendali (LOC) searah dengan learning agility (LA). Apabila lokus kendali (LOC) naik sebesar satu satuan maka learning agility (LA) akan naik sebesar 0.429 satuan, dengan asumsi variabel lainnya konstan. Sedangkan pada model persamaan 2 nilai koefisien jalur b3 sebagai penghubung variabel efikasi diri (ED) dengan kinerja karyawan (KK) bernilai positif sebesar 0,520. Hal ini menunjukkan bahwa kinerja karyawan (KK) akan meningkat sebesar 0,520 apabila efikasi diri (ED) naik sebesar satu satuan dengan asumsi variabel lain konstan. Koefisien jalur b4 bernilai positif sebesar 0,398, dapat disimpulkan bahwa lokus kendali (LOC) memiliki hubungan yang berlawanan arah dengan kinerja karyawan (KK) dan kinerja karyawan (KK) akan turun sebesar 0,398 apabila lokus kendali (LOC) naik sebesar satu satuan dengan asumsi bahwa variabel lain konstan atau 0 (nol). Nilai koefisien jalur b5 sebesar 0,184 dan positif atau searah. Apabila learning agility (LA) meningkat sebesar satu satuan maka kinerja karyawan (KK) akan naik sebesar 0,184 dengan asumsi bahwa variabel lainnya bernilai konstan atau 0 (nol).

Uji outer model atau uji evaluasi model dilakukan dengan mengevaluasi terhadap nilai konsistensi internal (cronbach's alpha dan composite reliability), validitas konvergen (AVE), validitas diskriminan (cross loading dan akar AVE). Konsistensi internal merupakan uji yang digunakan untuk mengukur tingkat reliabilitas alat ukur dalam penelitian. Nilai konsistensi internal menurut Santosa (2018:82) reliabel jika $\geq 0,7$ untuk instrument yang sudah teruji dan $\geq 0,5$ untuk instrument baru yang belum diuji. Hasil pengujian konsistensi internal pada penelitian ini yang telah memenuhi standar yang telah ditentukan dapat dilihat dari tabel 8 berikut ini: 
Tabel 2. Hasil Uji Konsistensi Internal

\begin{tabular}{lccc}
\hline \multicolumn{1}{c}{ Variabel } & $\begin{array}{c}\text { Cronbach's } \\
\text { Alpha }\end{array}$ & $\begin{array}{c}\text { Composite } \\
\text { Reliability }\end{array}$ & Keterangan \\
\hline Kinerja Karyawan (KK) & 0,894 & 0,922 & Reliabel \\
Learning Agility (LA) & 0,936 & 0,954 & Reliabel \\
Efikasi Diri (ED) & 0,923 & 0,946 & Reliabel \\
Lokus kendali (LOC) & 0,874 & 0,910 & Reliabel \\
\hline
\end{tabular}

Sumber: data diolah, 2021

Pada tabel hasil nilai konsistensi internal dapat diketahui nilai cronbach's alpha dan composite reliability pada setiap varibel penelitian lebih besar dari 0,7 . Hal tersebut dapat diartikan bahwa jawaban kuesioner akan tetap sama jika diukur pada objek yang sama meskipun menggunakan alat pengukur yang berbeda, diuji oleh peneliti yang berbeda dan di waktu yang berbeda.

Validitas konvergen yang memenuhi prasyarat menurut Hair (2017) dalam Santosa (83:2018) adalah nilai $\mathrm{AVE} \geq 0,5$ konstruk menjelaskan lebih dari setengah varians berasal dari indikatornya.

Tabel 2. Hasil Uji Validitas Konvergen

\begin{tabular}{lcc}
\hline \multicolumn{1}{c}{ Variabel } & AVE & Keterangan \\
\hline Kinerja Karyawan (KK) & 0,922 & Valid \\
Learning Agility (LA) & 0,954 & Valid \\
Efikasi Diri (ED) & 0,946 & Valid \\
Lokus kendali (LOC) & 0,910 & Valid \\
\hline
\end{tabular}

Sumber: data diolah, 2021

Nilai AVE pada semua variabel telah memenuhi syarat validitas konvergen karena bernilai lebih dari 0,5. Hal ini dapat diartikan bahwa kinerja karyawan (KK), learning agility (LA), efikasi diri (ED) dan locus of control (LOC) mampu menjelaskan lebih dari separuh varians yang berasal dari indikatornya.

Validitas diskriminan merupakan ukuran yang menunjukkan bahwa variabel-variabel dalam penelitian berbeda atau tidak menunjukkan korelasi yang tinggi antar variabel. Validitas diskriminan menurut Santosa (2018:83) diuji pada dua tingkat, yaitu tingkat indikator dan tingkat konstruk. Validitas diskriminan tingkat indikator disebut dengan cross loading, nilai outer loading dari indikator variabel itu sendiri harus lebih besar dari nilai outer loading indikator tersebut ke variabel lain dan nilai outer loading dari setiap variabel harus $\geq$ 0,7. Validitas diskriminan tingkat konstruk menggunakan nilai akar AVE, nilai akar AVE dari variabel itu sendiri harus lebih besar dari nilai akar AVE variabel tersebut ke variabel lain. 
Tabel 3. Hasil Nilai Cross Loading

\begin{tabular}{cccccc}
\hline \multicolumn{1}{c}{ Variabel } & & KK & LA & ED & LOC \\
\hline \multirow{4}{*}{ Kinerja Karyawan (KK) } & KK1 & 0,860 & 0,676 & 0,788 & 0,704 \\
& KK2 & 0,799 & 0,561 & 0,551 & 0,571 \\
& KK3 & 0,887 & 0,770 & 0,815 & 0,702 \\
& KK4 & 0,871 & 0,596 & 0,635 & 0,712 \\
& KK5 & 0,771 & 0,643 & 0,557 & 0,551 \\
\hline \multirow{5}{*}{ Learning Agility (LA) } & LA1 & 0,679 & 0,940 & 0,759 & 0,680 \\
& LA2 & 0,804 & 0,890 & 0,795 & 0,804 \\
& LA3 & 0,709 & 0,954 & 0,661 & 0,718 \\
Efikasi Diri (ED) & LA4 & 0,643 & 0,877 & 0,706 & 0,658 \\
& ED1 & 0,787 & 0,736 & 0,972 & 0,717 \\
& ED2 & 0,805 & 0,793 & 0,824 & 0,696 \\
& ED3 & 0,649 & 0,742 & 0,909 & 0,646 \\
& ED4 & 0,652 & 0,585 & 0,897 & 0,552 \\
\hline \multirow{5}{*}{ Lokus kendali (LOC) } & LOC1 & 0,530 & 0,616 & 0,625 & 0,766 \\
& LOC2 & 0,672 & 0,505 & 0,738 & 0,788 \\
& LOC3 & 0,713 & 0,761 & 0,658 & 0,936 \\
& LOC4 & 0,521 & 0,660 & 0,379 & 0,731 \\
& LOC5 & 0,729 & 0,658 & 0,597 & 0,856 \\
\hline
\end{tabular}

Sumber: data diolah, 2021

Nilai cross loading pada variabel dengan tiap indikatornya bernilai lebih dari 0,7 dan lebih tinggi dibandingkan dengan variabel lain. Variabel penelitian telah dapat memprediksi indikator pada blok mereka sendiri, sehingga terdapat korelasi yang valid dari setiap variabel dengan indikatornya sendiri.

Tabel 4. Hasil Uji Validitas Akar AVE

\begin{tabular}{lcccc}
\hline \multicolumn{1}{c}{ Variabel } & KK & LA & ED & LOC \\
\hline Kinerja Karyawan (KK) & 0,839 & & & \\
Learning Agility (LA) & 0,779 & 0,916 & & \\
Efikasi Diri (ED) & 0,811 & 0,801 & 0,902 & \\
Lokus kendali (LOC) & 0,779 & 0,786 & 0,732 & 0,819 \\
\hline
\end{tabular}

Sumber: data diolah, 2021

Nilai akar AVE pada setiap variabel memiliki nilai lebih besar dibandingkan dengan nilai korelasi suatu variabel dengan variabel lainnya.

Karakteristik responden karyawan PT. Bank Pan Indonesia, Tbk - cabang Tanjung Perak terdiri dari jenis kelamin, usia, pendidikan, dan jabatan. Berdasarkan jenis kelamin responden perempuan pada penelitian ini mendominasi sebanyak 20 responden, sedangkan responden laki-laki sejumlah 12 orang. Hasil perhitungan tersebut mengindikasikan bahwa perempuan lebih dominan daripada laki-laki karena perempuan dinilai lebih cekatan dan teliti dalam menghitung uang. Bersarkan usia jumlah responden terbanyak berusia 26-30 tahun sebanyak 9 orang, usia 20-25 tahun sejumlah 7 orang, usia 31-35 tahun sebanyak 6 orang, 
usia 36-40 tahun dan >40 tahun masing-masing sebanyak 5 orang. Hal tersebut berarti bahwa responden dalam penelitian ini bisa dikategorikan mempunyai usia yang cukup produktif dan mudah menerima informasi-informasi baru yang berguna untuk memudahkan dalam bekerja. Berdasarkan jabatan responden sebagai back office dengan jumlah 9 orang, account officer sebanyak 8 orang, funding officer 7 orang, customer services 5 orang, dan teller sebanyak 3 orang. Berdasarkan berdasarkan tingkat pendidikan responden dengan pendidikan S1 sangat dominan berjumlah 20, S2 berjumlah 7 orang, dan D3 sejumlah 5 orang. Hasil tersebut menandakan bahwa responden dalam penelitian ini memiliki kompetensi yang baik dalam menyelesaikan pekerjaan sesuai dengan target yang telah ditentukan.

Tabel 5. Deskriptif Variabel

\begin{tabular}{llccc}
\hline \multicolumn{1}{c}{ Variabel } & N & Minimum & Maksimum & Mean \\
\hline Kinerja Karyawan & 32 & 4,13 & 4,31 & 4,20 \\
Learning Agility & 32 & 4,13 & 4,34 & 4,24 \\
Efikasi Diri & 32 & 4,09 & 4,28 & 4,22 \\
Lokus kendali & 32 & 4,03 & 4,34 & 4,18
\end{tabular}

Sumber: data diolah, 2021

Dari tabel 5 dapat diketahui bahwa rata-rata deskriptif variabel adalah tinggi karena memiliki nilai rata-rata diatas 4,20. Secara umum dapat dikatakan bahwa karyawan PT Bank Pan Indonesia, Tbk - cabang Tanjung Perak Surabaya memiliki learning agility, efikasi diri, lokus kendali, dan kinerja yang positif terhadap kinerja.

Tabel 6. Distribusi Frekuensi Kinerja Karyawan

\begin{tabular}{|c|c|c|c|c|c|c|c|c|c|}
\hline \multirow[b]{2}{*}{ No } & \multirow[t]{2}{*}{ Indikator } & \multicolumn{5}{|c|}{ Frekuensi } & \multirow[b]{2}{*}{$\begin{array}{l}\text { Total } \\
\text { Skor }\end{array}$} & \multirow[b]{2}{*}{$\mathbf{N}$} & \multirow[b]{2}{*}{ Mean } \\
\hline & & $\begin{array}{c}\text { ST } \\
\text { S } \\
\end{array}$ & TS & $\begin{array}{l}\mathbf{K} \\
\mathbf{S}\end{array}$ & $\mathbf{S}$ & SS & & & \\
\hline 1 & Kuantitas Pekerjaan & 0 & 0 & 2 & 23 & 7 & 133 & & 4,15 \\
\hline 2 & Kualitas Pekerjaan & 0 & 0 & 0 & 24 & 8 & 136 & & 4,25 \\
\hline 3 & Ketepatan Waktu & 0 & 0 & 1 & 25 & 6 & 133 & 32 & 4,16 \\
\hline 4 & Kehadiran & 0 & 0 & 1 & 20 & 11 & 138 & & 4,31 \\
\hline \multirow[t]{2}{*}{5} & Kemampuan bekerjasama & 0 & 0 & 1 & 26 & 5 & 132 & & 4,13 \\
\hline & To & & & & & & 672 & & 4,20 \\
\hline
\end{tabular}

Sumber: data diolah, 2021

Berdasarkan tabel 6 diketahui nilai mean sebesar 4,20 masuk dalam kategori 3,40<a $\leq 4,20$ yang berarti responden penelitian setuju dengan pertanyaan kesioner kinerja karyawan. 
Tabel 7. Distribusi Frekuensi Learning Agility

\begin{tabular}{cccccccccc}
\hline \multirow{2}{*}{ No } & \multirow{2}{*}{ Indikator } & \multicolumn{9}{c}{ Frekuensi } & Total & \multirow{2}{*}{ N } & \multirow{2}{*}{ Mean } \\
\cline { 3 - 6 } & STS & TS & KS & S & SS & Skor & & \\
\hline 1 & People Agility & 0 & 0 & 0 & 24 & 8 & 136 & & 4,25 \\
2 & Result Agility & 0 & 0 & 1 & 26 & 5 & 132 & 32 & 4,13 \\
3 & Mental Agility & 0 & 0 & 1 & 22 & 9 & 136 & 4,25 \\
4 & Change Agility & 0 & 0 & 0 & 21 & 11 & 139 & & 4,34 \\
\hline & & Total & & & & 543 & 4,24 \\
\hline
\end{tabular}

Sumber: data diolah, 2021

Berdasarkan tabel 7 diketahui nilai rata-rata tanggapan responden sebesar 4,24, masuk dalam kategori 4,20< a $\leq 5,00$ yang berarti responden penelitian sangat setuju dengan pertanyaan kesioner learning agility.

Tabel 8. Distribusi Frekuensi Efikasi Diri

\begin{tabular}{|c|c|c|c|c|c|c|c|c|c|}
\hline \multirow{2}{*}{ No } & \multirow{2}{*}{ Indikator } & \multicolumn{5}{|c|}{ Frekuensi } & \multirow{2}{*}{$\begin{array}{l}\text { Total } \\
\text { Skor }\end{array}$} & \multirow{2}{*}{$\mathbf{N}$} & \multirow{2}{*}{ Mean } \\
\hline & & STS & TS & KS & $\mathbf{S}$ & SS & & & \\
\hline 1 & $\begin{array}{l}\text { Perasaan mampu } \\
\text { melakukan pekerjaan }\end{array}$ & 0 & 0 & 0 & 24 & 8 & 136 & \multirow{3}{*}{32} & 4,25 \\
\hline 2 & $\begin{array}{l}\text { Kemampuan yang lebih } \\
\text { baik }\end{array}$ & 0 & 0 & 3 & 23 & 6 & 131 & & 4,09 \\
\hline 3 & $\begin{array}{l}\text { Senang pekerjaan yang } \\
\text { menantang }\end{array}$ & 0 & 0 & 1 & 22 & 9 & 136 & & 4,25 \\
\hline 4 & $\begin{array}{l}\text { Kepuasan terhadap } \\
\text { pekerjaan }\end{array}$ & 0 & 0 & 0 & 23 & 9 & 137 & & 4,28 \\
\hline & & tal & & & & & 540 & & 4,22 \\
\hline
\end{tabular}

Sumber: data diolah, 2021

Berdasarkan tabel 8, nilai rata-rata tanggapan responden sebesar 4,22 masuk dalam kategori 4,20 $<\mathrm{a} \leq 5,00$ yang bermakna responden penelitian sangat setuju dengan pertanyaan-pertanyaan kesioner efikasi diri.

Tabel 9. Distribusi Frekuensi Lokus Kendali

\begin{tabular}{|c|c|c|c|c|c|c|c|c|c|}
\hline \multirow{2}{*}{ No } & \multirow{2}{*}{ Indikator } & \multicolumn{5}{|c|}{ Frekuensi } & \multirow{2}{*}{$\begin{array}{l}\text { Total } \\
\text { Skor } \\
\end{array}$} & \multirow{2}{*}{$\mathbf{N}$} & \multirow{2}{*}{ Mean } \\
\hline & & STS & TS & $\mathbf{K S}$ & $\mathbf{S}$ & SS & & & \\
\hline 1 & $\begin{array}{l}\text { Berpersepsi usaha harus } \\
\text { dilakukan jika ingin berhasil }\end{array}$ & 0 & 0 & 1 & 19 & 12 & 139 & & 4,34 \\
\hline 2 & Kurang mencari Informasi & 0 & 0 & 0 & 23 & 9 & 137 & & 4,28 \\
\hline 3 & Mudah menyerah & 0 & 0 & 3 & 22 & 7 & 132 & 32 & 4,13 \\
\hline 4 & Mudah dipengaruhi orang lain & 0 & 0 & 2 & 25 & 5 & 131 & & 4,09 \\
\hline 5 & $\begin{array}{l}\text { Kejadian dalam hidup akibat } \\
\text { orang berkuasa }\end{array}$ & 0 & 0 & 3 & 25 & 4 & 129 & & 4,03 \\
\hline & $\begin{array}{ll} & \text { Total } \\
\end{array}$ & & & & & & 668 & & 4,18 \\
\hline
\end{tabular}

Sumber: data diolah, 2021

Uji inner model terdiri dari uji koefisien determinasi $\left(\mathrm{R}^{2}\right)$ dan uji signifikansi keofisien jalur dan. Uji koefisien determinasi $\left(\mathrm{R}^{2}\right)$ menunjukkan nilai antara 0 sampai 1 , nilai yang mendekati 1 menunjukkan semakin besar akurasi prediksinya (Santosa, 2018:94-95). 
Tabel 10. Hasil Uji Koefisien Determinasi $\left(\mathbf{R}^{2}\right)$

\begin{tabular}{lcc}
\hline & R Square & Keterangan \\
\hline KK & 0,741 & Signifikan \\
LA & 0,727 & Tidak Signifikan \\
\hline
\end{tabular}

Sumber: data diolah, 2021

Sedangkan Santosa (2018:93) mengatakan bahwa jika nilai p-value > 0,05 maka efikasi diri, lokus kendali, dan learning agility secara langsung atau tidak langsung berpengaruh tidak signifikan terhadap kinerja karyawan dan hipotesis penelitian yang diajukan dapat diterima.

Tabel 11. Hasil Uji Signifikansi Koefisien Jalur

\begin{tabular}{lcll}
\hline \multicolumn{1}{c}{ Relasi } & P Values & \multicolumn{2}{c}{ Keterangan } \\
\hline $\mathrm{ED} \rightarrow \mathrm{KK}$ & 0,040 & Signifikan & $\mathrm{H}_{1}$ diterima \\
$\mathrm{LOC} \rightarrow \mathrm{KK}$ & 0,113 & Tidak Signifikan & $\mathrm{H}_{2}$ ditolak \\
$\mathrm{LA} \rightarrow \mathrm{KK}$ & 0,642 & Tidak Signifikan & $\mathrm{H}_{3}$ ditolak \\
$\mathrm{ED} \rightarrow \mathrm{LA} \rightarrow \mathrm{KK}$ & 0,001 & Signifikan & $\mathrm{H}_{4}$ diterima \\
$\mathrm{LOC} \rightarrow \mathrm{LA} \rightarrow \mathrm{KK}$ & 0,675 & Tidak Signifikan & $\mathrm{H}_{5}$ ditolak \\
\hline
\end{tabular}

Sumber: data diolah, 2021

Analisis data menunjukkan hubungan yang positif dan signifikan antara efikasi diri dengan kinerja karyawan. Efikasi diri berpengaruh positif dan signifikan terhadap kinerja karyawan. Hal ini berarti tingginya nilai efikasi diri pada karyawan dapat berpengaruh terhadap kinerja karyawan, dengan kata lain apabila perusahaan meningkatkan segala aspek yang mampu menumbuhkan efikasi diri karyawan maka kinerja karyawan dapat meningkat pula. Karyawan akan lebih semangat untuk mengerjakan tugasnya jika mereka memiliki tingkat kepercayaan diri yang cukup. Menurut teori atribusi karyawan yang terkontrol secara internal yang dicerminkan dengan usahanya akan lebih puas dengan pekerjaan mereka (Luthans, 2005: 342). Karyawan yang terkontrol secara internal menunjukkan kinerja yang lebih baik. Pada karyawan PT Bank Pan Indonesia, Tbk - cabang Tanjung Perak Surabaya dicerminkan dari sikap merasa mampu melakukan pekerjaannya dan merasa puas terhadap pekerjaannya. Karyawan menganggap pekerjaan yang dijalaninya saat ini dapat menjadikan mereka sukses dalam berkarir, sehingga tak jarang banyak karyawan yang semangat dalam melaksanakan tugasnya dengan baik meskipun pekerjaan tersebut belum pernah diketahui sebelumnya. Pada PT Bank Pan Indonesia - cabang Tanjung Perak Surabaya menumbuhkan rasa percaya diri karyawan dengan melatih mereka untuk berani berargumentasi pada saat rapat evaluasi rutin setiap bulannya. PT Bank Pan Indonesia Tbk - cabang Tanjung Perak Surabaya menganggap bahwa pada dasarnya setiap orang memiliki efikasi diri, efikasi diri akan terbentuk ketika perusahaan memberikan dukungannya sehingga karyawan dapat memberikan kinerja yang terbaik bagi perusahaan. Temuan dalam penelitian ini sejalan 
dengan beberapa penelitian lain diantaranya oleh Dewi dan Tenaya (2017), Mukrodi (2018), Zaki, et al (2019), Rofi (2019) yang secara konsisten menemukan bahwa efikasi diri berpengaruh signifikan terhadap kinerja karyawan, namun bertentangan dengan Hikmah (2020) menyatakan bahwa efikasi diri berpengaruh positif tidak signifikan terhadap kinerja karyawan.

Lokus kendali ditemukan berpengaruh positif dan tidak signifikan terhadap kinerja karyawan. Freitz Heider dalam teori atribusinya meyakini bahwa kekuatan internal dalam hal ini kelelahan dan usaha, serta kekuatan eksternal yang berupa atribut lingkungan seperti aturan perusahaan, keberuntungan, dan kesulitan tugas secara bersama-sama menentukan perilaku karyawan (Luthans, 2005: 210). Menggunakan lokus kendali, perilaku karyawan PT Bank Pan Indonesia, Tbk - cabang Tanjung Perak Surabaya dapat dijelaskan menggunakan penilaian terhadap hasil kerja, faktor internal dan eksternal apa yang mempengaruhinya. Karyawan PT Bank Pan Indonesia, Tbk - melakukan pekerjaannya dengan berusaha menarik simpati atasan yang dirasa dapat memudahkan memberi penilaian bagus dalam pekerjaannya. Menarik simpati atasan ini dipertegas oleh teori halo efek, dengan menciptakan persepsi positif kepada atasan akan menimbulkan citra baik karyawan didepan atasan (Lunthans, 2006: 208). Sehingga bagaimanapun pekerjaan yang dihasilkan tetap membuat atasan berfikir karyawan memiliki kinerja yang baik. Karyawan yang bekerja berdasarkan faktor luar akan mudah cepat bosan dan sering kali tidak optimal dalam bekerja karena karyawan akan merasa cukup ketika telah mencapai target yang telah ditentukan perusahaan. Bekerja pada sektor perbankan tidak asing dengan melakukan pekerjaan yang banyak sesuai target perusahaan dan monoton, sehingga mengakibatkan karyawan mudah merasa lelah karena secara psikologis melakukan kegiatan yang sama berulang-ulang akan mudah membuat merasa bosan dan tidak semangat dalam melakukan aktivitasnya yang akan berdampak pada penurunan kinerja. Pada karyawan PT Bank Pan Indonesia Tbk - cabang Tanjung Perak Surabaya ini mereka cenderung mudah menyerah jika menemui hal sulit serta malas untuk mencari informasi sehingga pekerjaan yang dihasilkan kurang optimal. Temuan ini sejalan dengan penelitian yang dilakukan oleh Subroto (2017) dan Amalini et al (2016), namun bertolak belakang dengan penelitian yang dilakukan oleh (Modise \& Rambe, 2016; Saprudin, et al., 2019).

Learning agility ditemukan berpengaruh positif dan tidak signifikan terhadap kinerja karyawan. Hal ini menunjukkan bahwa semakin tinggi nilai learning agility pada diri seorang karyawan maka akan semakin meningkatkan kinerjanya. Namun hasil pengolahan data yang dilakukan tidak bisa memastikan hubungan yang jelas antara learning agility terhadap kinerja karyawan. Learning agility merupakan kesediaan dan kemampuan seorang karyawan belajar 
dari pengalamannya kemudian hal tersebut diterapkan agar tidak melakukan kesalahan yang sama. Learning agility pada karyawan membuat mereka cepat mempelajari hal baru dan mau menerima feedback dari pekerjaan mereka sehingga dapat mempermudah pekerjaannya dan menghasilkan kinerja yang baik. Weiner dalam Luthans (2005) mengatakan bahwa dimensi stabilitas (tetap atau tidak tetap) dalam teori atribusi perlu diperhitungkan dan harus dikenali dalam menilai perilaku individu setiap karyawan. Karyawan yang memiliki pengalaman lebih memiliki atribusi internal yang lebih stabil tentang kemampuan mereka. Sedangkan kemauan dan usaha menjadi atribusi internal yang tidak stabil. Pada sisi lain karyawan mempunyai atribusi eksternal yang stabil yaitu aturan atau target pekerjaan, atribusi yang tidak stabil adalah kesulitan tugas. Pada karyawan PT Bank Pan Indonesia, Tbk - cabang Tanjung Perak Surabaya memiliki karyawan berusia $<30$ tahun sebanyak $50 \%$ dan berpendidikan diploma 3 dan strata 1 sebanyak 25 dari 32 karyawan anggota sampel. Hal ini berarti karyawan pada PT Bank Pan Indonesia, Tbk - cabang Tanjung Perak Surabaya didominasi oleh karyawan yang memiliki pengalaman yang kurang sehingga sedikit hal yang dapat mereka pelajari dari pengalamannya. Pekerjaan yang terlalu monoton akan membuat karyawaan menjadi tidak inovatif dan tidak memiliki inisiatif sehingga jika hal ini terjadi secara terus-menerus akan menyebabkan karyawan tidak suka terhadap tantangan. Selain itu, karyawan kurang bisa mengeksplor kemampuan yang ada pada dirinya meskipun mereka telah rutin mengikuti berbagai pelatihan yang diselenggarakan oleh perusahaan karena pemberian tugas yang cenderung sama dan banyak. Hal tersebut membuat karyawan menggunakan waktu kerjanya untuk mengerjakan tugas yang sama tanpa mengeksplor hal haru. Temuan penelitian ini sejalan dengan penelitian Drinka (2018) yang menyatakan bahwa learning agility berpengaruh positif tidak signifikan terhadap kinerja karyawan. Sedangkan pendapat Saputra et al. (2018) yang menyatakan bahwa learning agility memiliki pengaruh positif signifikan terhadap work engagement yang akan berdampak pada kinerja karyawan.

Efikasi diri dalam penelitian ini ditemukan berpengaruh positif namun tidak signifikan terhadap kinerja karyawan melalui learning agility. Hal ini berarti learning agility dapat memediasi pengaruh antara efikasi diri terhadap kinerja karyawan. Apabila perusahaan dapat meningkatkan efikasi diri karyawannya dan ditunjang dengan kecerdasan yang memumpuni, maka akan mempermudah karyawan dalam menyelesaikan pekerjaannya terutama pekerjaan baru yang dinilai cukup sulit. Bandura dalam Luthans (2005:342) mengatakan bahwa pengalaman seorang karyawan dengan usaha yang sungguh-sungguh dan didorong oleh kemampuan belajar dapat membentuk efikasi diri yang tinggi. Melalui daya tahan dan kemampuan belajar, karyawan mencari cara agar dapat mengendalikannya meskipun berada 
pada lingkungan dengan hambatan tinggi. Karyawan tidak ragu dalam menghadapi kesulitannya karena mereka dengan mudah meyakinkan diri sendiri bahwa mereka bisa dan beranggapan yang telah dilakukannya tidak sia-sia. Faktor utama yang membuat learning agility dapat memediasi adalah kemampuan karyawan untuk bisa belajar dari pengalaman, mampu melihat permasalahan dari berbagai sudut pandang dan memiliki rasa keingintahuan yang tinggi. Selain itu, karyawan yang memiliki kemampuan learning agility bagus akan mudah dalam mempelajari hal baru didalam sebuah pekerjaan. Sehingga hal ini membuat karyawan lebih percaya diri karena menganggap diri mereka memiliki potensi yang bagus dibandingkan rekan lainnya. Pada karyawan PT Bank Pan Indonesia Tbk - cabang Tanjung Perak Surabaya membuktikan ketika karyawan mau dan mampu mempelajari hal baru akan membuat mereka lebih semangat dan percaya diri yang mengakibatkan meningkatnya hasil kinerja karyawan. Penelitian serupa dilakukan oleh Desiana (2019) yang menyatakan bahwa efikasi diri berpengaruh signifikan secara tidak langsung terhadap kinerja karyawan melalui inovasi. Efikasi diri yang tinggi akan membentuk inovasi karyawan sehingga secara tidak langsung dapat meningkatkan kinerjanya.

Lokus kendali dalam penelitian ini ditemukan memiliki pengaruh positif dan tidak signifikan terhadap kinerja karyawan melalui learning agility. Hal ini berarti learning agility tidak dapat memediasi pengaruh antara lokus kendali terhadap kinerja karyawan. Kemampuan mempelajari hal baru tidak dapat memediasi pengaruh lokus kendali untuk meningkatkan kinerja karyawan, meskipun berpengaruh positif tetapi hal tersebut tidak memiliki pengaruh yang berdampak. Pada setiap karyawan mempunyai kemampuan berdasarkan pada pengetahuan, keterampilan, dan kompetensi sesuai dengan bidang pekerjaannya. Namun, karyawan juga memiliki persepsi terhadap kontrol atas dirinya sehingga dapat membentuk kepribadian, sikap, perilaku yang bisa mempengaruhi kinerjanya (Luthans, 2005). Berdasarkan teori atribusi, faktor internal dari karyawan PT Bank Pan Indonesia Tbk cabang Tanjung Perak Surabaya yaitu usaha yang sungguh-sungguh dalam meraih kesuksesan dan kemampuannya, sedangkan faktor eksternalnya adalah target, dan kondisi lingkungan kerja, kesulitan dalam mengerjakan tugas. Pada karyawan PT Bank Pan Indonesia, Tbk cabang Tanjung Perak Surabaya memiliki kemampuan learning agility yang baik dalam keempat aspeknya (people agility, result agility, mental agility, dan change agility), karyawan menggunakan kemampuan learning agility untuk berusaha dalam meningkatkan kinerjanya. Hanya saja usaha yang dilakukan lebih kepada arah eksternal lokus kendali yaitu karyawan percaya bahwa terdapat faktor luar yang dapat mempengaruhi hidupnya seperti orang berkuasa dalam hal ini yaitu atasan kerja. Sehingga karyawan menggunakan akan 
meningkatkan kinerjanya dengan kemampuannya untuk menarik simpati atasan, namun karyawan dengan persepsi ini tidak dapat bertahan lama untuk meningkatkan kinerja karyawan karena jika kemauan meningkatkan kinerjanya tidak berasal dari diri sendiri karyawan akan cepat bosan dan menyerah ketika dihadapkan pada situasi yang sulit. Keyakinan diri akan selalu mengambil kendali akan diri kita, semakin seseorang memiliki pengalaman yang ditunjang kemampuan learning agility yang bagus maka semakin bisa pula kita mengendalikan diri kita. Responden pada penelitian ini didominasi oleh karyawan yang masih muda, masih sedikit pengalaman sehingga mereka gampang untuk dipengaruhi dan menganggap faktor luarlah yang memiliki pengaruh besar akan hidupnya yang membuat mereka tidak optimal dalam bekerja. Penelitian serupa dilakukan oleh Rivai (2021) yang menyatakan bahwa lokus kendali tidak memiliki efek mediasi terhadap kinerja melalui keterikatan karyawan.

\section{KESIMPULAN DAN SARAN}

Berdasarkan perhitungan menggunakan SmartPLS menunjukkan: Efikasi diri berpengaruh positif dan signifikan terhadap kinerja karyawan, lokus kendali berpengaruh positif dan tidak signifikan terhadap kinerja karyawan, learning agility berpengaruh positif dan tidak signifikan terhadap kinerja karyawan, efikasi diri berpengaruh positif dan signifikan terhadap kinerja karyawan melalui learning agility, dan lokus kendali berpengaruh positif dan tidak signifikan terhadap kinerja karyawan melalui learning agility. Hasil penelitian ini menunjukkan bahwa karyawan cenderung memiliki kinerja yang bagus apabila mereka memiliki tingkat keperayaan diri atau efikasi diri yang tinggi, ditambah lagi ditunjang dengan kemampuan learning agility agar memudahkan karyawan mengerjakan hal baru, bisa bertahan didalam keadaan yang tidak mudah dan dapat mendapat feedback dari pengalaman ataupun rekan kerjanya. Hal ini penting, bahwa suatu keberhasilan kinerja perusahaan ditentukan oleh kinerja para karyawannya dan sangat bergantung terhadap bagaimana perusahaan memperlakukan karyawannya agar dapat menumbuhkan efikasi diri dan mengasah kemampuan learning agilitynya. Penelitian ini memiliki keterbatasan, seperti: penelitian ini hanya menggunakan teori atribusi, sementara masih ada teori lain dan dapat menjelaskan faktor yang mempengaruhi kinerja karyawan; keterbatasan literatur tentang learning agility untuk mengungkapkan pengaruh hubungan antar variabel penelitian terhadap kinerja karyawan; penulis dalam melihat hal yang mempegaruhi kinerja karyawan hanya menggunakan tiga variabel, yaitu efikasi diri, lokus kendali dan learning agility. Masih terdapat pengaruh lain yang mempengaruhi kinerja karyawan yang tidak diteliti dalam 
penelitian ini; penelitian ini terbatas pada perusahaan perbankan, yaitu PT Bank Pan Indonesia Tbk - cabang Tanjung Perak Surabaya. Sementara masih banyak karyawan pada perusahaan lain yang belum diteliti. Peneliti menyarankan: perusahaan hendaknya dapat mempertahankan strategi yang dapat meningkatkan efikasi diri karyawan, karyawan harus dikelola dengan baik agar mereka merasa nyaman dalam melakukan pekerjaannya dan secara tidak langsung dapat memberikan hasil kerja terbaiknya kepada perusahaan. Serta mempertahankan program membeikan penghargaan kepada karyawan yang berkinerja tinggi. Hal ini mendorong karyawan dalam meningkatkan efikasi dirinya dan melakukan kinerja yang optimal; perusahaan hendaknya dapat memberikan pandangan terhadap karyawannya bahwa kesuksesan ditentukan oleh diri mereka bukan orang lain, sehingga untuk bisa meraih kesuksesan dalam berkarir karyawan harus berusaha dan memberikan pekerjaan terbaiknya; perusahaan hendaknya dapat meningkatkan learning agility karyawan dengan kegiatan pelatihan ataupun kegiatan lain yang dapat meningkatkan kreativitas agar suasana kantor tidak terlalu monoton dan menjadikan karyawan suka terhadap tantangan; perusahaan sudah cukup bagus dalam meningkatkan efikasi diri karyawan, hendaknya perusahaan bisa mempertahankan hal tersebut. Perusahaan lebih memberikan afirmasi positif dan memberikan penghargaan kepada karyawannya yang berprestasi sehingga mereka lebih merasa dihargai dan loyal terhadap perusahaan. Hendaknya PT Bank Pan Indonesia, Tbk - cabang Tanjung Perak Surabaya mendorong pemikiran kreatif seperti mengadakan lomba inovasi antar karyawan sehingga bisa menimbulkan kreativitas, inovasi, mengasah kemampuan learning agility sehingga dapat meningkatkan efikasi diri pada karyawan; perusahaan hendaknya lebih mengoptimalkan proses evaluasi kerja rutin setiap bulan dan mengevaluasi penialaian kinerja yang perlu diperbaiki sehingga karyawan lebih mudah tertantang dengan target yang telah diberikan perusahaan; dan untuk penelitian yang akan datang dalam meneliti lokus kendali dan learning agility agar meneliti pada organisasi diluar sektor perbankan atau organisasi yang belum terbentuk secara baik manajemennya untuk mengetahui seberapa besar keinginan individu dalam mempercayai dirinya sendiri.

\section{REFERENSI}

Allen, J. (2016). Conceptualizing Learning Agility and Investigating its Nomological Network. Disertasi. Florida International University.

Amalini, H. F., Musadieq, M. A., Afrianty, T. W. (2016). Pengaruh Locus of Control terhadap Kepuasan Kerja dan Kinerja. Jurnal Administrasi Bisnis (JAB), 36(1): 68-77.

Bandura, A. (2011). Self Efficacy Mechanism in Psikological and Health Promoting Behavior. Prentice Hall: New Jersy.

Bedford, C. L. (2011). The Role of Learning Agility in Workplace Performance and Career 
Advancement. Disertasi. University of Minnesota.

Choiriah, A. (2013). Pengaruh Kecerdasan Emosional, Kecerdasan Intelektual, Kecerdasan Spiritual, dan Etika Profesi terhadap Kinerja Auditor dalam Kantor Akuntan Publik (Studi Empiris pada Auditor dalam Kantor Akuntan Publik di Kota Padang dan Pekanbaru). Jurnal Akuntansi, 1(1): 3-22.

Desiana, N. E. (2019). Pengaruh Efikasi Diri Terhadap Kinerja Karyawan melalui Inovasi sebagai Variabel Intervening (Studi pada Divisi Sekretariat dan Humas PDAM Surya Sembada Kota Surabaya. Jurnal Ilmu Manajemen, 7(2): 382-392.

Dewi, I. G. A. P. dan Tenaya, A. I. (2017). Pengaruh Etika Profesi, Efikasi diri, Kecerdasan Spiritual, Kecerdasan Intelektual, dan Kecerdasan Emosional terhadap Kinerja Auditor. E-Jurnal Akuntansi Universitas Udayana, 19(1): 654-682.

Drinka, G. A. O. (2018). Coaching for Learning Agility: The Importance of Leader Behavior, Learning Goal Orientation, and Psychological Safety. Disertasi. Columbia University.

Hikmah, A. N. (2020). Pengaruh Reward dan Efikasi Diri terhadap Kinerja Dimediasi Variabel Motivasi. JIMMU Jurnal Ilmu Manajemen, 5(2): 188-205.

Luthans, F. (2005). Organizational Behavior (10th Edition). New York: McGraw Hill.

Mangkunegara, A. P. (2014). Manajemen Sumber Daya Manusia Perusahaan. Bandung: PT. Remaja Rosda Karya.

Mathis, R. L. dan Jacson, J. H. (2011). Human Resource Management. (10th Edition). Texas: Cengage Learning.

Meuse, K. P. D. (2019). A Meta-Analysis of The Relationship Between Learning Agility and Leader Success. Journal of Organizational Psychology, 19(1): 25-34.

Modise, D dan Rambe, P. (2017). Internal and External Locus of Control of Engineering Workforce in a Power Distribution Utility: Implication for Job Performance. African Journal of Business and Economic Research, 12 (2): 113-147.

Mukrodi. (2018). Pengaruh Efikasi Diri terhadap Kinerja Karyawan PT Express Kencana Lestari (Express Group) Depok. J Kreatif, 12 (2): 88-94.

Nainggolan, M. A., Kojo, C., dan Sendow, G. (2018). Analisis Pengaruh Internal Locus of Control dan External Locus of Control terhadap Kepuasan Kerja serta Dampaknya terhadap Kinerja Tenaga Kependidikan di Fakultas Ekonomi dan Bisnis Universitas SAM Ratulangi. Jurnal EMBA, 6(4): 4023-4032.

Panin Bank. 2020. Prestassi dan Reputasi Panin Bank. https://www.panin.co.id/pages/97/prestasi-dan-reputasi. Agustus 2021 (11.38).

Rofi, A. N. (2019). Efikasi Diri, Beban Kerja dan Kepuasan Sebagai Faktor Penentu Kinerja Pegawai. Journal of Economics and Banking, 1(2): 96-107.

Saprudin, T., Rosyaty, dan Syukron, A. (2019). Relationship between Organizational Culture and Locus of Control with Bogor Regency Employee Performance. International Review of Management and Marketing, 9(4): 143-148.

Saputra, N., Abdinagoro, S. B., dan Kuncoro, E. A. (2018). The Mediating Role of Learning Agility on the Relationship between Work Engagement and Learning Culture. Pertanika Journals, 26(T): 117-130.

Sugiyono. (2017). Metode Penelitian Kuantitatif, Kualitatif, Kualititatif, dan R\&D. Bandung: Alfabeta.

Subroto, S. (2017). Analisis Pengaruh Locus of Control dan Stress Kerja terhadap Kinerja Pegawai. Jurnal Riset Manajemen dan Akuntansi, 8(1): 35-44.

Wibowo. (2014). Manajemen Kinerja (Edisi ke 4). Jakarta: Rajawali Pers.

Zaki, W., Ali, A., Bakar, A., dan Sarwar, B. (2019). Role of Self-Efficacy in the Relationship of Training and Employee Performance. Paradigms, 13(1): 67-74. 